\title{
Ett försök att på empirisk väg belysa grunderna för judiciell straffutmätning
}

\author{
Av professor INKERI ANTTILA \\ och med. lic. ACHILLES WESTLING.
}

\section{Inledning}

Principiellt sett kan man anse, att utmätandet av straff såsom påföljd för brott sker på två olika nivåer: vid den straffrättsliga lagstiftningen, då man stadgar arten och storleken av påföljden för vissa som brott betraktade gärningar, samt vid domstolsförfarandet, då strafflagens bestämmelser tillämpas på ett konkret fall. Den av författarna företagna undersökningen har uteslutande koncentrerat sig på frågan om grunderna för straffutmätning i den senare bemärkelsen, dvs. den judiciella straffutmätningen. Däremot har straffutmätningen på det legislativa planet beaktats endast i den omfattning dess bestämmelser återspeglas i den judiciella straffutmätningen.

De genom lagstiftningen angivna straffnormerna är nuförtiden nästan uteslutande relativa, dvs. blott den lägsta och högsta gränsen för det teoretiskt ifrågakommande straffet har fastslagits. I en del fall upptar lagen flere skalor varav en kan betraktas som huvudskala medan de övriga kan anses vara biskalor ansedda för vissa särfall. Utöver dessa i anslutning till vart och ett brott angivna skalor bör domstolen ytterligare beakta de eventuellt ifrågakommande straffskärpande och straffnedsättande grunder som uppräknas i strafflagens allmänna del och som de facto konstituerar ytterligare ett antal straffskalor.

Sedan valet av straffskala är klart gäller det att inom skalans latitud utmäta straffet. Den finska strafflagen ger dock icke lika litet som flertalet övriga strafflagar - närmare direktiv för hur detta skall ske. Enda undantaget är bestämmelserna om återfall som försvårande omständighet. Däremot har man inom rättsvetenskapen ägnat grunderna för straffutmätningen en hel del uppmärksamhet. Man har allmänt varit av den åsikten, att domstolen vid sina avgöranden bör ha straffets olika funktioner för ögonen, dvs. såväl vedergällning som straffets allmän- och individualpreventiva uppgifter. Därtill har man ansett, att analogi bör tillämpas vid straffutmätningen: straffskärpande eller straffnedsättande bestämmelser som upptagits i något visst lagrum, kan under vissa förutsättningar tillämpas även på andra brott. Straffutmätningsgrunder, som härvid har nämnts är t. ex. rättskränkningens kvantitativa omfattning, den uppståndna skadans storlek, sättet för brottets utförande, gärningsmannens ålder och 
tidigare livsföring ävensom huruvida han är att betrakta som yrkes- eller vaneförbrytare.

Domstolarna råkar ofta i svårigheter när de i avsaknad av uttryckliga förhållningsregler skall tillämpa lagens vittomfattande straffskalor. Det är naturligt, att de då söker stöd i tidigare rättspraxis, vilket kan leda till uppkomsten av ett sk. taxeringssystem: man använder sig av vissa på förhand mer eller mindre fastslagna straffkvantiteter. Man kan dock tala om taxeringssystem i olika bemärkelser beroende på hur schematiskt respektive differentierat det avsedda systemet fungerar, dvs. hur många och vilka faktorer som beaktas vid straffutmätningen. Den ena ytterligheten är då, att för brott som tillhör samma kategori alltid utmäts samma straff utan att något avseende fästes vid eventuella skillnader vare sig beträffande brottet eller gärningsmannen. Mera differentierat är systemet t. ex. då domstolen beaktar en eller flere omständigheter som ansluter sig till själva brottet, men lämner gärningsmannens personliga egenskaper, levnadshistoria och återfallsprognos obeaktade. Och som motsatt ytterlighet har vi fallet då domaren - samtidigt som han fortfarande går efter vissa fastslagna normer - tar hänsyn till så många faktorer som möjligt. I den mån domaren verkligen lyckas förena dessa två principer, i den mån sammanfaller taxering med en långt individualiserad, men dock interindividuellt enhetlig rättsskipning.

Frågan om grunderna för straffutmätningen är viktig ur flere synpunkter: den är inte enbart av judiciellt intresse utan den ansluter sig oskiljaktligt till frågan om individens rättsskydd, dvs. i sista hand till frågan om tillämpningen av ,,similia similibus"-principen i rättskipningen. Men frågeställningen är aktuell också för kriminalpolitiken, där såväl samhällets intressen som straffets individuella syften måste beaktas. Och ur fånguppfostrans synvinkel är frågan såtillvida betydelsesfull, att domstolens utslag kommer icke endast att ha en väsentlig inverkan på själva arten och längden av det straff individen faktiskt har att utstå utan det sammanhänger också med i vilken mån fången upplever de samhälleliga sanktioner han gjorts till föremål för, som berättigade eller inte.

Empiriska undersökningar rörande den judiciella straffutmätningen är påfallande få. Dels torde detta sammanhänga med ett särskilt hos jurister väl förståeligt avvisande ställningstagande gentemot frågeställningar av detta slag, dels med vissa rent praktiska svårigheter, såsom till ex. vanskligheten att iakttaga och klassificera alla de olika faktorer som med fog kan tänkas ha inverkat på avgörandet. En till grunden gående undersökning borde nämligen omfatta förutom fakta som direkt anknyter sig till brottet och den anklagade också data om domstolen och olika omständigheter som ansluter sig till själva rättegångsförfarandet: 
t. ex. domstolens uppfattning om gärningsmannens motiv, den åtalades beteende efter gärningen samt vid rättegången, målsägarnas inställning till det skedda, domarens attityd till brottet i fråga osv. En undersökning som utförts i efterhand, på basen av handlingar, kan följaktligen endast belysa en del av de faktorer som i praktiken kan ha inverkat på straffutmätningen.

\section{Undersökningens syfte}

Syftet med den av oss föranstaltade undersökningen har varit att i görlig mån försöka klarlägga vissa av de faktorer som inom den undersökta brottskategorin står i korrelation till de utdömda straffen.

En väsentlig svårighet vid empiriska undersökningar av straffutmätning är att de enskilda brotten för de flesta brottsarters vidkommande erbjuder en synnerligen vid uppsättning både „kvalitativa“ och "kvantitativa“ variationsmöjligheter. För att i så hög grad som möjligt kunna eliminera denna (ur straffutmätningssynpunkt antagligen särdeles fundamentala) faktor har vi i denna undersökning valt som objekt ett brott, där själva den kriminaliserade gärningen är i de olika fallen så likformig som möjligt. Det mest lämpliga brottet ansåg vi vara fångrymning, som i Finland varit kriminaliserat sedan år 1931.1) Rymning är ju et brott, som till sitt ,,innehåll“ och omedelbara syfte — att undgå det återstående straffet och ernå frihet - är från fall till fall synnerligen likformigt. Denna konformitet accentueras ytterligare därav, att rymning som planerats av två eller flere få̉ngar enligt Finlands strafflag bestraffas som ett specialfall av myteri (SL 16 kap. $12 \S$ ). Om åter till rymningen ansluter sig övriga brott, t. ex. våldsdåd eller egendomsbrott, fastställs för dessa skilda straff och först därefter sammanräknas dessa med straffet för rymning. ${ }^{2}$ )

Om också undersökningen uteslutande befattar sig med rymningsfall, är det icke denna brottsart som sådan vi vill granska; utan vi vill endast belysa straffutmätningsgrunderna inom ramen för detta brott. I överensstämmelse med detta faller det helt utan-

1) Fångrymning kriminaliserades i Finland den 13.5.1931 genom ett tillägg till strafflagen $(16 \mathrm{kap} .11 \mathrm{~b} \S)$. Enligt detta tillägg skall fånge som rymmer eller gör försök att rymma, ,från straffanstalt, fängelse eller annat förvar eller från den, som bevakar, ledsagar eller forslar honom" straffas med fängelse i minst en månad och högst två år.

2) Undantag från denna regel är blott de fall då brotten utförts "genom en handling", dvs. då sk. ideell konkurrens föreligger. 
för undersökningens ram att bedöma den straffskala som fastställts för detta brott eller att ta upp frågan huruvida det överhuvudtaget är ändamålsenligt att kriminalisera rymning. ${ }^{3}$ )

\section{Materialet för undersökningen}

Undersökningen baserar sig på material av tvenne slag: på uppgifter erhållna från Statistiska centralbyrån om rymningsfallen i landet för hela den tidsrymd gärningen i fråga varit kriminaliserad samt på ett av oss närmare analyserat rymmarmaterial.

Det senare omfattar underrätternas handlingar i samtliga fall av fångrymning i Finland åren 1952-56. Namnen på fångarna har erhållits ur en förteckning som justitieministeriets fångvårdsavdelning för över envar som gör sig skyldig till rymning. Utgående från denna förteckning har handlingarna rörande rymningen erhållits ur centralfångregistret eller av de enskilda fängelserna.

Vårt material omfattade ursprungligen 342 personer. Före bearbetningen uteslöts följande fall:

- de kvinnliga rymmarna, sammanlagt 3 .

— ett fall där fången fortfarande var på fri fot.

— ett fall där en livstida tukthusfånge fått sitt straff i form av ljus ensamcell.

- 11 fall där rätten förkastat åtalet för rymning.

— 16 fall där handlingarna inte var tillgängliga på grund av att fången avlidit.

- 27 fall, där handlingarna av andra orsaker inte var tillgängliga eller uppgifterna bristfälliga.

Av de återstående rymmarna hade 31 dömts för myteri och 252 för rymning. Dessa 252 manliga rymmare bildar det slutgiltiga materialet för vår undersökning.

\section{De vid undersökningen granskade faktorerna}

På basen av de från Statistiska centralbyrån erhållna uppgifterna har straffen för rymning granskats i förhållande till tidsperiod och kön.

3) Dessa problem vore otvivelaktigt värda en speciell kriminalpolitisk utredning, eftersom fångrymning f. n. är ett brott endast i några få stater i Europa (utom i Finland, Bulgarien, England, Grekland, Italien, Sovjetunionen och Tcheckoslovakien). I Finland kunde man dessutom undersöka de ,dubbla“ påföljder rymmare blir utsatta för genom at de blir föremål för såväl det av domstolen ådömda straffet som vissa disciplinära sanktioner inom fängelset. Ytterligare vore det skäl att jämföra systemet med de sanktioner som används i anslutning till arbetskolonisystemet. Den som avlägsnar sig från en arbetskoloni döms inte för rymning, men måste i stället avtjäna sitt straff från början i ett vanligt fängelse. Beroende på tidpunkten fär rymningen blir denna sanktion följaktligen än mildare, än strängare än de straff som rymmare ur slutna inrättningar döms till. 
På basen av vårt eget material har vi granskat skilt A) legala faktorer samt B) övriga faktorer som kan tänkas ha inverkat på straffutmätningen. Till den förra kategorin hör

A) Legala faktorer

a) Ungdom. Personer vars ålder vid tidpunkten för rymningen var $15-17$ år skall enligt SL 3 kap. $2 \S$ dömas enligt en mildare skala. ${ }^{4}$ )

b) Tillräknelighet. De som dömts såsom varande i avsaknad av förståndets fulla bruk, (de „förminskat tillräkneliga“) skall enligt strafflagens 3 kap. 4 § dömas till mildare straff. ${ }^{5}$ )

c) Försök. De som gjort sig skyldiga till rymningsförsök. Trots att enligt Finlands strafflag rymningsförsök, i motsats till försök i allmänhet, icke har en separat straffskala, fanns det anledning att undersöka huruvida försök i praktiken ändå skulle bestraffas mildare än den fullbordade handlingen.

d) Återfall. I enlighet med återfallsbestämmelserna indelades materialet i tre undergrupper: a) de för vilkas del återfall icke förelåg, b) de, för vilkas del domstolen hade tillämpat stadgandena i strafflagens 6 kap. $1 \S$ samt c) de för vilkas del samma kapitels $2 \S$ hade tillämpats. ${ }^{6}$ ) De sistnämnda har ytterligare indelats $\mathrm{i}$ två undergrupper beroende på om personerna i fråga dömts enligt den första eller andra satsen av sagda paragraf. ${ }^{7}$ )

4) SL 3:2 lyder: "Begås brott av den, som fyllt femton, men icke aderton år, skall när dödsstraff eller tukthus på livstid kunnat följa å brottet, dömas till tukthus från och med två till och med tolv år. I övriga fall vare straffet i allmän straffart högst tre fjärdedelar av strängaste straff, som i varje straffart för brottet är stadgat, och lägst det minsta belopp, som i en var av dessa straffarter enligt 2 kap. får ådömas. Stadgas för brottet ej annat straff i allmän straffart än tukthus på viss tid; må ock kunna dömas till fängelse i högst tre fjärdedelar av längsta tiden för det tukthusstraff, dock ej över fyra år, och lägst den minsta tid, på vilken fängelse enligt sagda kap. får ådömas.“

5) SL 3:4 lyder: „Prövas någon, som begått brott, hava därvid saknat förståndets fulla bruk, fastän han ej kan enligt $3 \S$ anses för otillräknelig: vare straff i allmän straffart såsom i 2 § sägs. (Se ovan SL $3: 2$ ). Ej må i detta fall rus eller annan dylik sinnesförvirring, vilken gärningsmannen själv ådragit sig, allena gälla såsom skäl till sådan straffnedsättning."

6) SL 6:1 lyder: „Begår den, som till fullo eller till en del utstått tukthusstraff eller direkt ådömt fängelsestraff eller ett bötesstraff av minst sjuttiofem dagsböter, brott, på vilket kan följa frihetsstraff utöver tre månader, skall den omständigheten, att han tidigare blivit avstraffad, anses vara försvårande, såvida icke 2 § skall tillämpas.“

7) SL 6:2 lyder: „Har någon, sedan han för ett eller flere brott antingen i en eller flere skilda omgångar utstått tukthusstraff eller direkt ådömt fängelsestraff under minst ett år, begått brott, för vilket strängaste straffet kan utgöra frihetsstraff på viss tid, ej under sex månader, varde därför, såvida icke brottet bör anses vara begånget under mildrande omständigheter, för återfall i brott dömd till tukthus eller, om å brottet kan följa fängelse, antingen till tukthus eller fängelse, till 
B. Övriga faktorer

e) typen av anstalt vid rymningen

f) ålder

g) arten av det pågående straffet

h) totallängden av det pågående straffet

i) rymningssituationen

j) antal tidigare rymningar

k) förekomst av övriga brott $i$ anslutning till rymningen

1) domstolen som utdömt straffet.

\section{Metoden vid analysen av resultaten}

I vårt försök att belysa grunderna fär utmätning av straff vid rymning har vi beaktat dels straffets art, dels dess längd.

De straffarter som kan användas vid rymning är fängelse eller tukthus - tukthus dock endast då det är frågan om återfallsförbrytare enligit SL 6:2. Grunderna för valet mellan fängelseoch tukthusstraff har i dessa fall undersökts på basen av frekvensjämförelser, varvid signifikansen av eventuella differenser uppskattats med användning av t-test.

Undersökningen av straffens längd har skett genom jämförande av medeltalet $\left(\mathrm{m}_{1}\right)$ för strafftiderna för rymning i respektive grupper. Signifikansen är uppskattad som ovan.

Enligit Finlands strafflag förvandlas fängelsestraff till tukthus genom att från fängelsestraffet avdra en fjärdedel. På grund av att vid olika indelningar av materialet frekvensen av tukthusstraff varierar förmår icke blotta medeltalet av strafftiderna ge en adekvat bild av straffens genomsnittliga „stränghet“ inom respektive grupp. För att på denna punkt komplettera vår analys har vi — som ett något fiktivt mått för straffens genomsnittliga „totalkvantitet“ inom respektive grupp — uträknat medeltalet för strafftiderna på basen av ovannämnda omräkningsprincip. Det med bokstaven $\mathrm{m}_{2}$ betecknade talet är sålunda medeltalet för strafftiderna, då strafftidens längd för de individers vidkommande, som dömts till tukthus för rymningen, omräknats genom att öka längden av strafftiden med en tredjedel. Man erhåller då samma inbördes relation mellan straffen som då man enligt strafflagen förvandlar fängelsestraff till tukthus.

tukthus i högst en och en halv gång den för brottet stadgade längsta tiden för frihetsistraff eller till fängelse i högst en och en halv gång den därför stadgade längsta tiden för fängelsestraff. Har den brottslige tidigare utstått straff på sätt ovan sägs under minst tre år, må straffet vara tukthus högst tvă gånger den för brottet stadgade längsta tiden för frihetsstraff eller fängelse högst två gånger den därför stadgade längsta tiden för fängelsestraff. Den som undergått frihetsstraff i ett år, må dock ej dömas till tukthus över femton och den, som utstått straff i tre år, över tjugo år. 
Vid sidan av straffens längd har vi även fäst uppmärksamhet vid deras varians, dvs. det statistiska spridningsvärdet, för att genom detta skapa oss en bild av hur enhetligt, respektive oenhetligt, utmätandet av straffitiderna varit inom respektive grupper. Spridningen (dispersionen) har vi räknat ut enligt den gängse formeln för standardavvikelsen $(\sigma)$

$$
\sigma=\sqrt{\frac{\sum(\mathrm{x} \mu-\mathrm{M})^{2}}{\mathrm{n}}}
$$

På grund av att det absoluta talvärdet för $\sigma$ står — ifall spridningsfigurerna är likformiga - i direkt proportion till motsvarande variabels medeltal $(\mathrm{M})$, måste man anse, att spridningstalet ensamt icke kan ge en nöjaktig bild av den faktiska variansen, än mindre kan den tjäna som mått vid jämförelser av grupper med olika medeltal. Detta har föranlett oss att i stället for $\sigma$ använda oss av den sk. relativa spridningen (variationskoefficienten), dvs. kvoten av spridningen och medeltalet, ett tal som oberoende av medeltalet - bör anses vara ett adekvat mått på graden av enhetlighet (eller oenhetlighet) vad beträffar strafftiderna inom respektive grupp.

\section{Resultat.}

A. Straffutmätning enligt rättsstatistiken.

På basen av de från Statistiska centralbyrån erhållna uppgifterna har det varit möjligt att följa med domstolspraxis ända sedan dess rymning kriminaliserades, dvs. från år 1931. Iakttagelser om användningen av tukthus- respektive fängelsestraff är det åter möjligt att göra fr. o. m. år 1941, då de nuvarande bestämmelserna om återfall trädde i kraft och det blev möjligt att använda tukthusstraff för dem som dömdes enligt SL 6:2.

Då man följer med de straff som personer som gjort sig skyldiga till rymning eller försök till rymning dömts till, kan man konstatera, att praxis har varierat betydligt under olika tidsperioder..$^{8}$ ) För männens vidkommande var fängelsestraffens längd under 1930-talet $i$ allmänhet under 5 månader. I anslutning till de förändrade bestämmelserna om återfall, som trädde i kraft år 1941, kan man konstatera en väsentlig skärpning av straffen (något som också det rådande krigstillståndet antagligen bidrog till). Utom att man nu började använda tukthusstraff blev också fängelsestraffen längre: strafftidernas medeltal (m1) för tiden 1941-45 är 8,14 månader. Också under åren närmast efter kriget var straffen relativt stränga: motsvarande

8) På grund av att rättsstatistiken endast ger upplysningar om de fall av rymning, där rymning har betraktats som "huvudbrott“, har de åtföljande siffrorna uträknats på basen av dessa fall. 

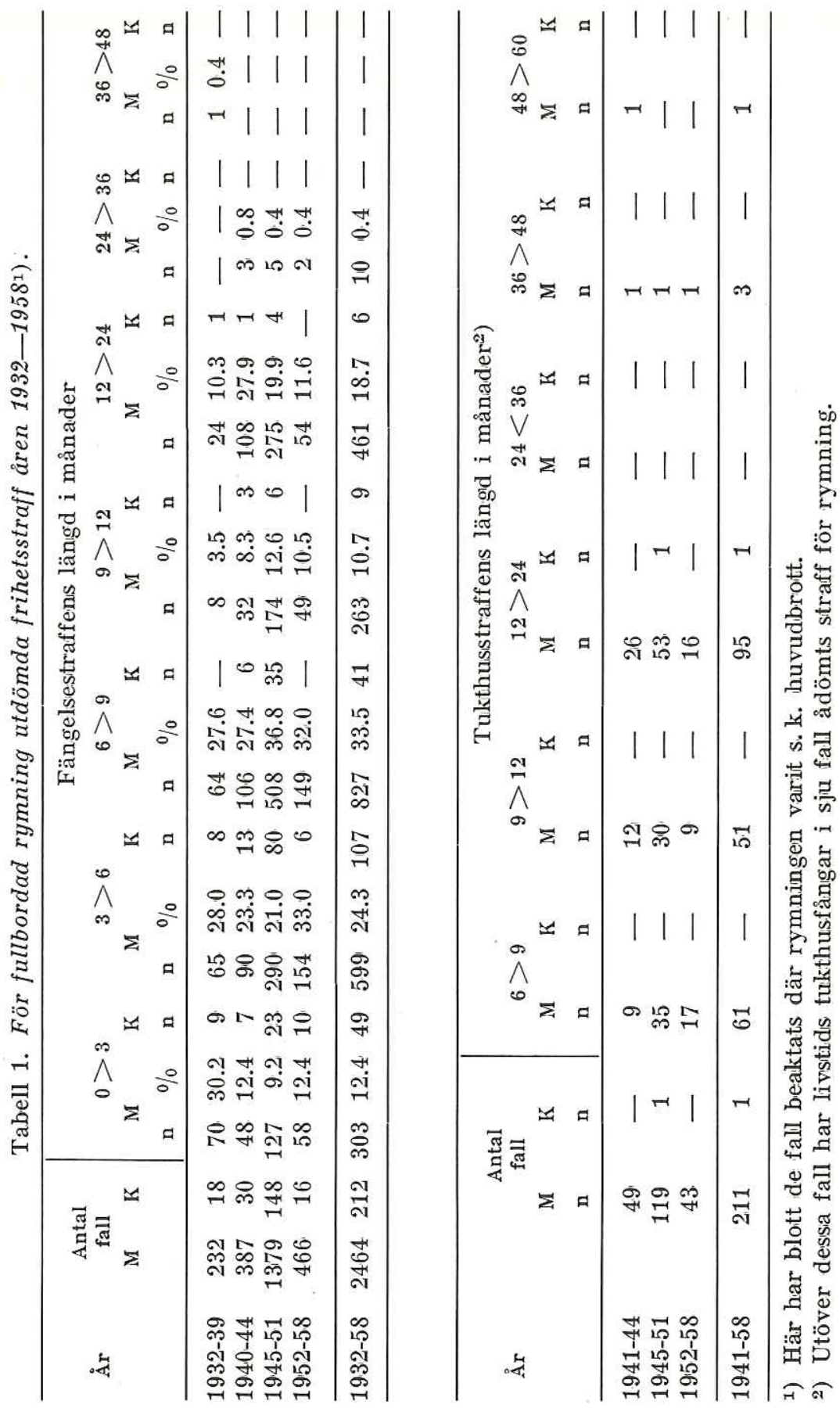
medeltal för åren 1946-51 är 7.40 månader. Sedan dess har straffen blivit något kortare och medeltalet för åren 1952-58 är 6.15 månader.

De straff som kvinnor dömts till för rymning och försök till rymning har under olika perioder undergått samma förändringar som straffen för männen. Till sin absoluta längd har de dock varit betydligt kortare. Strafftidernas genomsnittliga längd var på 1930-talet 3.33 månader, under kriget 4.70, under åren 1946 - 51 4.65 och under åren $1952-58$ blott 2.62 månader.

Även beträffande straffarten kan man observera skillnader mellan straffen för manliga och kvinnliga rymmare. Fr. o.m. 1941 t. o. m. 1958 har sammanlagt 2405 män dömts för rymning som huvudbrott; av dessa har 211 , dvs. $8.8 \pm 0.58 \%$ erhållit tukthusstraff, de övriga fängelsestraff. Under samma tid har sammanlagt 212 kvinnor dömts och av dem har 1, dvs. $0.47 \pm 0.44 \%$ dömts till tukthus, de övriga till fängelse. Skillnaden är signifikant.

Om det också är uppenbart, att kvinnliga och manliga rymmare, vad beträffar straffskärpande omständigheter, inte helt kan jämföras med varandra, är dock skiljaktigheterna vad beträffar såväl straffens längd som straffarten så pass påtagliga, att man med skäl kan säga att domstolarna här tillämpat en betydligt strängare straffskala på manliga rymmare.

\section{B. Straffutmätning $i$ det av förf. undersökta materialet.}

\section{1) Straffen $i$ hela materialet.}

Tabell 2 ger en bild av straffens fördelning mellan fängelse och tukthus ävensom av strafftidernas längd $i$ hela materialet. För jämförelsens skull har motsvarande uppdelning av straffen för myteri framlagts i tabell 3 . Såsom av tabellerna framgår, är proportionen av till tukthus dömda bland myterifallen betydligt större än bland rymmarna; också strafftidernas genomsnittliga längd är i denna grupp större.

\section{2) Valet av straffart vid rymning.}

a) Legala faktorer.

Av de för rymning dömda männen har sammanlagt 139 dömts enligt SL 6:2 - det är alltså blott för denna grupps vidkommande två alternativ har förelegat beträffande straffarten. Av dessa 139 personer dömdes 114 till fängelse och 25 till tukthus.

På grund av att SL 6:2 icke kan tillämpas på individer under 18 år är den mildare straffskala som betingas av SL 3:2 icke aktuell i detta sammanhang.

Vid en närmare granskning av de övriga „legala“ faktorernas förhållande till valet av straffart har vi konstaterat följande:

Försök: Av de 139 männen hade 11 gjort sig skyldiga till rym- 


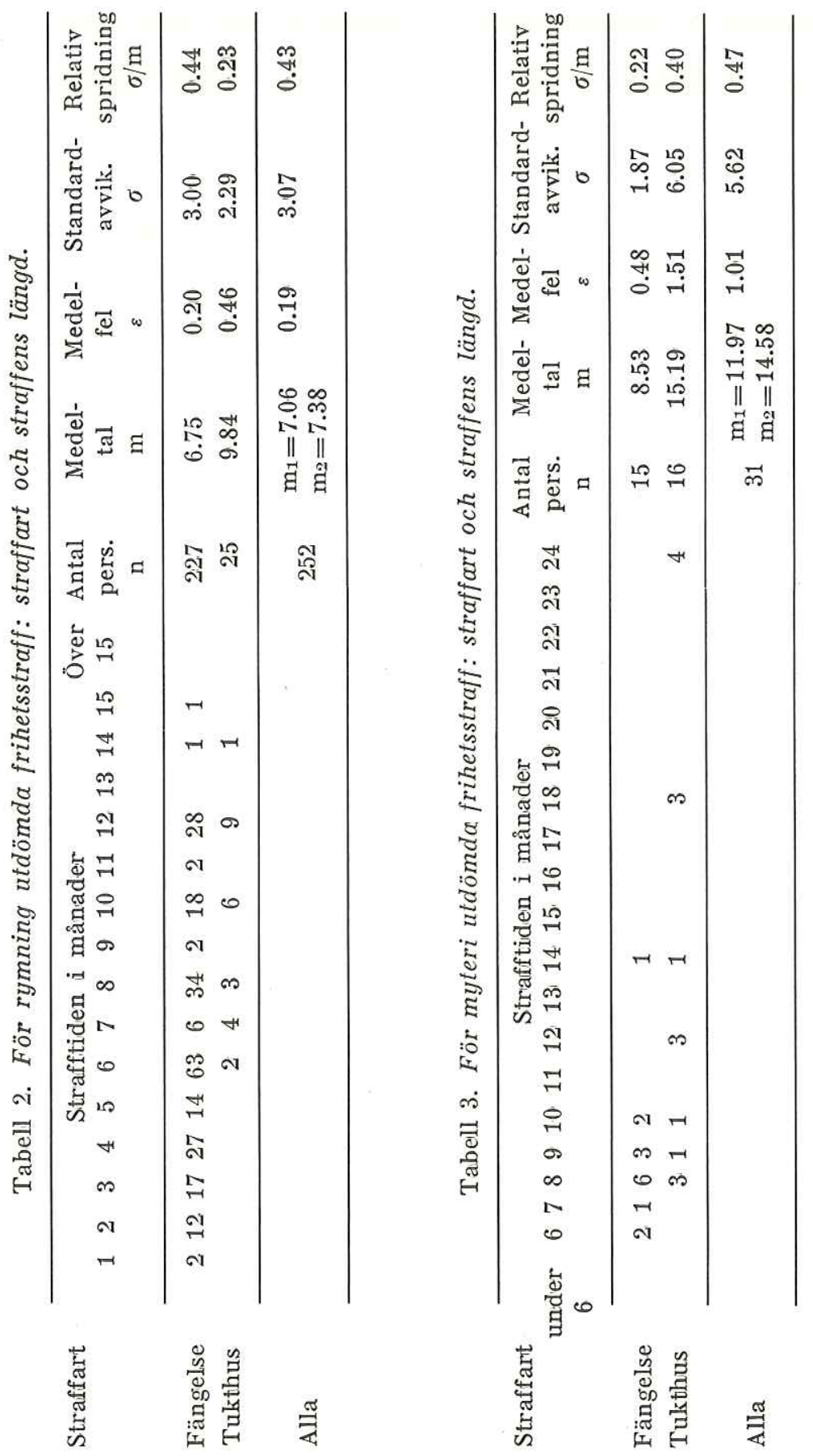


ningsförsök medan 128 hade dömts för fullbordat brott. Ingen av de förra hade dömts till tukthus. Differensen mellan tukthusfrekvensen för försök och fullbordat brott är närapå signifikant $(\mathrm{p}<0.05)$. Det är dock synnerligen rimligt att anta, att om materialet skulle ha omfattat ett större antal för försök dömda, skulle också p:s värde visat en mera signifikant differens. — På basen av detta har vi också vid den fortsatta analysen av valet av straffart hållit de för försök dömda isär från det övriga materialet.

Förminskad tillräknelighet. Av de 128 män som dömts för fullbordad rymning hade 13 dömts såsom varande $\mathrm{i}$ avsaknad av förståndets fulla bruk (enligt SL $3: 4$ ) och de övriga 115 som fullt tillräkneliga. Till tukthus hade av de förra dömts 5 dvs. $38 \%$ : motsvarande procent för de fullt tillräkneliga var däremot 17.4. Ehuru det förra procenttalet icke är signifikant högre än det sistnämnda, är resultatet under inga omständigheter $\mathrm{i}$ samklang med lagen som stadgar att en mildare straffskala skall användas för de minskat tillräkneliga. - På grund av att de minskat tillräkneliga icke dömts enligt enhetliga och klart identifierbara principer var det icke motiverat att vid den fortsatta analysen behandla dem separat.

Återfall. Av de ovannämnda 128 männen hade 37 dömts på grund av första satsen av SL $6: 2$ och 91 på grund av den andra (se sid. 5). Av de förra dömdes $2(5.4 \pm 4.6 \%)$ till tukthus, av de senare $23(25.3 \pm 4.6)$. Skillnaden är signifikant $(\mathrm{p}<0.002)$. Resultatet visar, att för rymning utdömes tukthus så gott som uteslutande då gärningsmannen uppfyller förutsättningarna för tillämpning av 2. satsen av ovannämnda paragraf; i dessa fall dömes ungefär var fjärde till tukthus. - På grund av denna ojämna fördelning av tukthusstraff beroende på vilken sats som tillämpats, har vid den fortsatta analysen de rymmare uteslutits som dömts enligt den första satsen.

\section{b) Icke-legala faktorer.}

I det följande skall vi nu göra ett försök att finna förklaringsgrunder till varför 23 (men dock blott 23 ) av dessa 91 män, som dömts för fullbordad rymning enligt den andra satsen av SL $6: 2$, har dömts till tukthus, medan de övriga 68 dömdes till fängelse.

I tabell 4 uppräknas en del faktorer, om vilka det var plausibelt att anta att de skulle stå i korrelation til förekomsten av tukthusdomar.

Såsom framgår av tabell 4, ser det ut som om fångar som är yngre än 25 år ävensom fångar som har att avtjäna ett straff under 2 år mera sällan skulle för rymningen dömas till tukthus. Dessa bägge kategorier bildar dock en minoritet, varför det återstår att förklara straffartsfördelningen i det övriga materialet. Personer som rymt ur anstalt av sluten typ ser även ut att oftare 
Tabell 4. För fullbordad rymning enligt SL 6:22)-dömda män; frekvensen av tukthusstraff $i$ förhållande till vissa icke-legala faktorer.

\begin{tabular}{llccc}
\hline & högst 2 år & $\begin{array}{c}\text { till } \\
\text { fängelse } \\
\text { dömda }\end{array}$ & $\begin{array}{c}\text { till } \\
\text { tukthus } \\
\text { dömda }\end{array}$ & $\begin{array}{c}\text { total- } \\
\text { antalet }\end{array}$ \\
\hline Det pågående & 14 & 3 & 17 \\
straffets längd ${ }^{1}$ ) & över 2 år & 51 & 18 & 69 \\
Det pågående & fängelse & 59 & 20 & 79 \\
straffets art & tukthus & 9 & 3 & 12 \\
Rymmarens ålder & högst 25 år & 11 & 1 & 12 \\
& över 25 år & 57 & 22 & 79 \\
Antal tidigare & ingen & 16 & 7 & 23 \\
rymningar & en & 22 & 7 & 29 \\
& två eller flere & 30 & 9 & 39 \\
Övriga brott i & icke övriga brott & 39 & 14 & 53 \\
anslutning till & övriga brott & 29 & 9 & 38 \\
rymningen & & & & \\
Platsen för & inne i anstalten & 28 & 9 & 37 \\
rymningen & utanför anstalten $\left.{ }^{2}\right)$ & 22 & 7 & 29 \\
Anstaltstyp & öppen, halvöppen & & & \\
& anstalt & 34 & 5 & 39 \\
& sluten anstalt & 34 & 18 & 52 \\
\hline
\end{tabular}

1) Rannsakningsfångar har här utelämnats.

2) övriga alternativ har icke beaktats.

dömas till tukthus än rymmare ur öppen eller halvöppen anstalt. Vad detta eventuellt beror på låter sig dock icke på grund av materialets ringa omfång utrönas. Av större intresse är det däremot att konstatera, att det pågående straffets art, antal tidigare rymningar samt brott i anslutning till rymningen icke ser ut att stå i korrelation till frekvensen av tukthusstraff. Även den omständigheten huruvida rymningen ägt rum från en plats inne i eller utanför anstalten ser ut att vara ovidkommande vid valet mellan fängelse och tukthus. Det visar sig således att ingen av de ovan anförda faktorerna förmår förklara, varför somliga av de enligt SL 6:2 $2^{2}$-dömda rymmarna döms till tukthus och somliga inte.

\section{De för rymning utmätta straffens längd.}

I anslutning till kapitlet A har en tabell över straffens fördelning i förhållande till art och längd redan framlagts för materialet som helhet. Vid en fortsatt differentiering av materialet 
enligt olika indelningsgrunder i syfte att uppdaga eventuella korrelationer till de utdömda straffens längd och spridning har — börjande åter med de i lagen uppräknade faktorerna — följande samband konistaterats:

\section{1) Legala faktorer.}

a) Ungdom. Då man jämför straffitiderna för rymmare under och över 18 år (tabell 5) finner man att de för rymning utdömda frihetsstraffens medellängd $i$ den förra gruppen är $3.92 \pm 0.38$ månader och $\mathrm{i}$ den senare $\left(\mathrm{m}_{1}\right) 7.21 \pm 0.20$ månader. Skillnaden är mycket signifikant $(\mathrm{p}<0.001)$. Också den relativa spridningen är mindre inom den yngre gruppen (spridningsvärdena är 0.33 respektive 0.42 ). Straffen för rymmarna under 18 år har sålunda — i överensstämmelse med lagen — varit både mildare och enhetligare än för de övriga. Strafftiderna för dessa unga rymmare - som alltså blott kan dömas till fängelse — varierar från 1 till 6 månader: någon absolut enhetlighet är det alltså inte heller här fråga om. På grund av att strafftiderna för rymmare under 18 år sålunda är avsevärdt kortare än för de övriga har denna grupp vid den fortsatta analysen lämnats åsido.

b) Tillräknelighet. Om man - efter det personer, som vid förövande av brottet varit under 18 år, uteslutits - indelar rymmarna i fullt och förminskat tillräkneliga kommer medeltalet för de utdömda strafftiderna att vara något högre för den senare kategorin (se tabell 6). Det visar sig dock, att samtliga som dömts som förminskat tillräkneliga även råkar vara enligt 6:2 dömda återfallsförbrytare. Om jämförelsen nu utföres så, att endast personer som dömts enligt sagda lagrum beaktas, visar det sig, att medeltalen ( $\left.\mathrm{m}_{1}\right)$ för strafftiderna för fullt och minskat tillräkneliga (tabell 8 och 6 )) är 8.55 respektive 8.20 månader - skillnaden är dock icke signifikant. Men ur legal synpunkt är icke heller denna jämförelse helt adekvat. Enligt lagen är nämligen skalan beträffande straffets längd för de förminskat tillräkneliga endast $3 / 4$ av skalan för de fullt tillräkneliga: om nu detta beaktas visar det sig att medeltalet för de förminskat tillräkneliga, 8.20, är anmärkningsvärt längre än $3 / 4$ av medeltalet för de fullt tillräkneliga, vilket är 6.42. Synbarligen på grund av det ringa antalet är signifikansen av differensen dock endast symptomatisk $(\mathrm{p}<0.10)$. Om man däremot utför samma kalkyl på basen av straffens ,totalkvantitet", visar det sig, att motsvarande tal är 9.25 och 6.86 , varvid differensen även är signifikant. Av tabellerna 6 och 8 kan man vidare utläsa, att inom sagda kategori återfallsförbrytare är strafftidernas relativa spridning för fullt och förminskat tillräkneliga 0.36 resp. 0.45 , dvs. straffutmätningen har skett mera oenhetligt för de förminskat tillräkneligas vidkommande. 
Tabell 5. För rymning utdömda frihetsstraff: rymmare under och över 18 års ålder.

Strafftiden i månader

$\begin{array}{llllllllllllllll}1 & 2 & 3 & 4 & 5 & 6 & 7 & 8 & 9 & 10 & 11 & 12 & 13 & 14 & 15 & \text { pers. }\end{array}$

Antal $\mathrm{m}$

$12 \mathrm{~m}=3.92 \quad 0.38$

1.31

Under 18 år

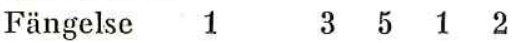

Tukthus

över 18 år

Fängelse

$\begin{array}{lllll}1 & 12 & 13 & 22 & 1\end{array}$

$\begin{array}{llllllll}13 & 61 & 6 & 34 & 2 & 18 & 2 & 28\end{array}$

1

$\begin{array}{lll}2 & 4 & 3\end{array}$

6
1
$215 \mathrm{~m}_{1}=7.21 \quad 0.20 \quad 3.06$

$25 \quad \mathrm{~m}_{2}=7.55$

Tabell 6. Fullt tillräkneliga och minskat tillräkneliga rymmare ådömda frihetsstraff. ${ }^{1}$ )

Strafftiden i månader

Antal

$\begin{array}{llllllllllllllll}1 & 2 & 3 & 4 & 5 & 6 & 7 & 8 & 9 & 10 & 11 & 12 & 13 & 14 & 15 & \text { pers. }\end{array}$

$\mathrm{m}$

$\varepsilon \quad \sigma$

Minskat

tillräkn.

Fängelse

Tukthus

$\begin{array}{lllll}1 & 1 & 1 & 1 & 2\end{array}$

$\begin{array}{lllll}1 & 1 & 2 & 3 & 1 \\ & & 1 & \end{array}$

$10 \quad \mathrm{~m}_{1}=8.20 \quad 0.95 \quad 3.67$

$5 \quad \mathrm{~m}_{2}=9.25$

övriga

Fängelse

$\begin{array}{llllllllllll}1 & 11 & 13 & 21 & 12 & 59 & 6 & 34 & 2 & 18 & 2 & 25\end{array}$

$1 \quad 205 \quad \mathrm{~m}_{1}=7.15 \quad 0.20 \quad 2.99$

Tukthus

$\begin{array}{lll}2 & 3 & 2\end{array}$

$\begin{array}{lll}4 & 8 & 1\end{array}$

$20 \quad \mathrm{~m}_{2}=7.44$

1) Personer under 18 år har inte tagits med.

Tabell 7. För rymningsförsök och fullbordad rymning utdömda frihetsstraff. ${ }^{2}$ )

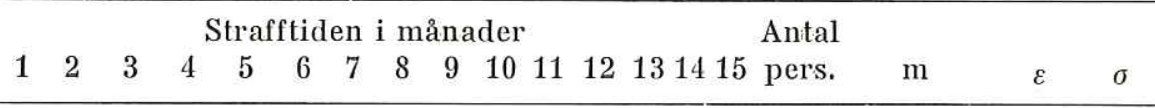

Försök

Fängelse

$\begin{array}{llll}5 & 3 & 2 & 6\end{array}$

2

1

$19 \mathrm{~m}=5.32 \quad 0.51$

2.22

Tukthus

Fullbordad

rymning

Fängelse

Tukthus

$\begin{array}{llllllllllll}1 & 11 & 8 & 18 & 10 & 53 & 6 & 32 & 2 & 18 & 2 & 24\end{array}$

$\begin{array}{llll}1 & 186 & \mathrm{~m}_{1}=7.32 & 0.21\end{array}$

2.99

$\begin{array}{lll}2 & 3 & 2\end{array}$

$\begin{array}{lll}4 & 8 & 1\end{array}$

$20 \quad \mathrm{~m}_{2}=7.64$

2) Personer under 18 år samt rymmare som dömts såsom förminskat tillräkneliga har inte tagits med. 
c) Försök. Tabell 7 visar (detta gäller alltså fullt tillräkneliga rymmare över 18 år) att strafftidernas medelital $\left(m_{1}\right)$ för dem som gjort sig skyldiga till fullbordad rymning (7.32 \pm 0.21$)$ är signifikant högre än motsvarande medeltal för dem som gjort sig skyldiga till rymningsförsök $(5.32 \pm 0.51)$. Då man ytterligare beaktar, att tukthusstraff inte använts för dem som dömts för försök, blir skillnaden vad beträffar straffens ,totalkvantitet“" $\left(\mathrm{m}_{2}\right)$ ännu större. Strafftidernas relativa spridning är för dem som dömts för försök 0.42 och för dem som dömts för fullbordad rymning 0.41 . Att rymningen stannat vid ett försök synes sålunda leda till att strafftiden i genomsnitt blir kortare: däremot tycks straffutmätningen inte bli enhetligare.

d) Aterfall. För att klarlägga återfallsbestämmelsernas inverkan har materialet (exclusive personer under 18 år, förminskat tillräkneliga samt personer dömda för försök till rymning) uppdelats i tre kategorier (tabell 8). För gruppen icke-återfall var strafftidernas medeltal $\left(m_{1}\right) 5.68 \pm 0.38$, för de enligt SL $6: 1$

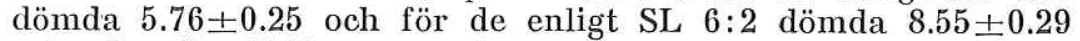
månader. Strafftidernas medeltal var sålunda för de båda förra grupperna ungefär det samma - skillnaden var blott $2 \%$ medan medeltalet för den senare gruppen var signifikant högre $(\mathrm{p}<0.001)$. På basen av resultaten synes det ändamålsenligt att behandla icke-återfallsförbrytare och „SL 6:1“ som en grupp och „SL 6:2“ som en grupp. Den relativa spridningen, uträknad på basen av $\mathrm{m}$, är $\mathrm{i}$ den förstnämnda förenade gruppen 0.34 , i den senare 0.36 .

I undergruppen ,SL 6:2“ är det skäl att skilt för sig granska dem som dömts enligt 1 och 2 satsen. Det visar sig då (tabell 9) att strafftidernas medeltal enligt $\mathrm{m}_{1}$ blir 8.55 månader för vardera gruppen. Däremot existerar en skillnad såtillvida, att tukthusstraffet, såsom tidigare konstaterats, praktiskt taget uteslutande kommit till användning för dem som dömts enligt 2 satsen. Medeltalet enligt $\mathrm{m}_{2}$ blir för dem som dömts enligt 1 satsen 8.75 och för dem som dömts enligt 2 satsen 9.29. Den relativa spridningen är för dem som dömts enligt 1 satsen 0.33 och för dem som dömts enligt 2 satsen 0.38 . Det förefaller alltså som om straffförfarandet för den senare gruppens del eventuellt skulle vara något mindre enhetligt.

Eftersom såväl strafftiderna som strafftidernas relativa spridning är ganska lika för dem som dömts enligt 1 respektive 2 satsen, kan de båda grupperna behandlas som en enda, så länge blott strafftidernas längd och spridning jämförs. Däremot måste man, på grund av tukthusstraffens asymmetriska fördelning, hålla grupperna i sär vid en granskning av straffens ,totalkvantitet". 
Tabell 8. För fullbordad rymning utdömda frihetsstraff och tillämpningen av bestämmelserna om återfall.*)

Strafftiden i månader

Antal

$\begin{array}{lllllllllllllllll}1 & 2 & 3 & 4 & 5 & 6 & 7 & 8 & 9 & 10 & 11 & 12 & 13 & 14 & 15 & \text { pers. }\end{array}$

Icke-återf.

Fängelse

$\begin{array}{llllll}1 & 6 & 2 & 10 & 1 & 2\end{array}$

$22 \mathrm{~m}=5.68$

$0.38 \quad 1.77 \quad 0$

SL $6: 1$

Fängelse

$\begin{array}{llllllll}6 & 5 & 9 & 4 & 24 & 2 & 16 & 3\end{array}$

$69 \quad \mathrm{~m}=5.78 \quad 0.25 \quad 2.06 \quad 0$

SL $6: 2$

Fängelse

Tukthus

$\begin{array}{llll}1 & 5 & 2 & 3\end{array}$

$\begin{array}{llllllll}4 & 19 & 4 & 15 & 2 & 13 & 2 & 24\end{array}$

$\begin{array}{llllll}2 & 3 & 2 & 4 & 8 & 1\end{array}$

Alla

206

Tabell 9. För fullbordad rymning utdömda frihetsstraff enligt SL 6:21, respektive $\left.6: 2^{2} .^{*}\right)$

\begin{tabular}{|c|c|c|c|c|c|c|c|c|c|c|c|c|c|c|c|c|c|c|}
\hline & & & & & tra & ftic & en & $\mathrm{i} \mathrm{m}$ & $\mathrm{in}$ & der & & & & Antal & & & & \\
\hline & 1 & 2 & 3 & 4 & 5 & 6 & 7 & 8 & 9 & 10 & 11 & 12 & 131415 & pers. & $\mathrm{m}$ & $\varepsilon$ & $\sigma$ & a \\
\hline$S L \quad 6: 2^{1}$ & & & & & & & & & & & & & & & & & & \\
\hline Fängelse & & 1 & & 1 & 2 & 6 & & 5 & 1 & 6 & 1 & 8 & & 34 & $\mathrm{~m}_{1}=8.55$ & 0.47 & 2.79 & 0 \\
\hline Tukthus & & & & & & & & & & 1 & & 1 & & 2 & $\mathrm{~m}_{2}=8.75$ & & & \\
\hline$S L \quad 6: 2^{2}$ & & & & & & & & & & & & & & & & & & \\
\hline Fängelse & 1 & 4 & 2 & 2 & 2 & 10 & 4 & 10 & 1 & 7 & 1 & 16 & 1 & 61 & $\mathrm{~m}_{1}=8.55$ & 0.36 & 3.22 & 0. \\
\hline Tukthus & & & & & & 2 & 3 & 2 & & 3 & & 7 & 1 & 18 & $\mathrm{~m}_{2}=9.29$ & & & \\
\hline
\end{tabular}

*) I tabellen har inte medtagits personer under 18 år och rymmare som dömts såsom förminskat tillräkneliga; ej heller personer dömda för rymningsförsök.

\section{2) Övriga faktorer.}

Förrän man börjar granska de faktorer som inverkat på strafftidernas längd måste ytterligare en undergrupp utelämnas ur materialet, nämligen de fall där en permitterad fånge försenat sig vid återkomsten till fängelset. Av dessa fångar har en dömts enligt SL 6 kap. $1 \S$ och tre enligt samma kapitels $2 \S$. Medellängden av deras frihetsstraff är knappa 2 månader. Eftersom dessa fall ur kriminologisk synpunkt med skäl kan betraktas som undantagsfall, har de i det följande lämnats ur räkningen.

Härefter skall i tur och ordning ett antal faktorer granskas som inte finns med bland de i lagen uttryckligen utsagda bestäm- 
Tabell 10. För fullbordad rymning utdömda frihetsstraff enligt anstaltstyp. $\left.{ }^{1}\right)$

\begin{tabular}{llllll}
\hline $\begin{array}{l}\text { Anstalts- } \\
\text { typ }\end{array}$ & $\begin{array}{c}\text { Antal fall } \\
\text { Fängelse Tukthus }\end{array}$ & $\mathrm{m}$ & $\varepsilon$ & $\sigma$ & $\sigma / \mathrm{m}$ \\
\hline
\end{tabular}

Sluten

öppen, halvöpp.

Ungdomsfäng.

Sluten

öppen, halvöpp.

Ungdomsfäng.

a) Icke-återfall och $S L 6: 1$

$\begin{array}{llllll}28 & \ldots & 7.15 & 0.37 & 1.91 & 0.27 \\ 22 & \ldots & 5.30 & 0.49 & 2.18 & 0.41 \\ 40 & \ldots & 5.12 & 0.20 & 1.25 & 0.24\end{array}$

b) $S L 6: 2$

1) I denna och följande tabeller har rymmary under 18 år samt rymmare som dömts såsom förminskat tillräkneliga inte tagits med.

melserna, men om vilka man i alla fall kan antaga, att de står i en viss relation till de utdömda straffens längd.

a) Anstaltstyp., Tabell $10 \mathrm{a}$ visar, att strafftidernas medeltal är i bägge undergrupperna längre för dem som rymt från en sluten än för dem som rymt från en öppen eller halvöppen anstalt. Däremot visar det sig — inom undergrupp ,,icke återfall och SL $6: 1^{\prime \prime}$ — att den genomsnittliga strafftiden för rymmare ur ungdomsfängelse har varit närapå lika lång som strafftiden för rymmare ur öppen eller halvöppen anstalt. Strafftidernas relativa spridning är dock lägre för rymmare ur ungdomsfängelse: denna större enhetlighet vid bestraffandet av rymmare ur ungdomsfängelse torde bero på att majoriteten av dem dömts vid samma domstol.

b) Fångens ålder. Tabell 11 visar, att i undergruppen ,ickeåterfall och SL 6:1" har rymmarna $i$ åldern 18-20 år fått $i$ genomsnitt något kortare straff än de övriga: medeltalet för åldersgruppen $18-20$ år är $5.38 \pm 0.23$ månader. Om man emellertid delar upp denna ålderskategori i a) de som rymt från ungdomsfängelse och b) de som rymt från någon annan anstalt, finner man att strafftidernas medeltal för den förra gruppen är $5.03 \pm 0.26$ månader och för den senare $6.00 \pm 0.59$ månader. Då tidigare dessutom har konstaterats, att nästan alla som rymt från ungdomsfängelse har dömts vid samma underrätt, som genomgående använder milda straff, tyder resultaten på, att strafftiderna i allmänhet inte skulle vara kortare för åldersgruppen 18-20 än för andra, utan att skillnaderna sammanhänger med praxis vid nämnda underrätt. 
Tabell 11. För fullbordad rymning utdömda frihetsstraff enligt rymmarnas ålder vid tidpunkten för rymningen.

\begin{tabular}{|c|c|c|c|c|c|c|}
\hline Ålder & $\begin{array}{r}\text { Ant } \\
\text { Fängels }\end{array}$ & $\begin{array}{l}\text { fall } \\
\text { Tukthus }\end{array}$ & $\mathrm{m}$ & $\varepsilon$ & $\sigma$ & $\sigma / \mathrm{m}$ \\
\hline \multicolumn{7}{|c|}{ a) Icke-återfall och $S L 6: 1$} \\
\hline $18-20$ & 42 & . & $\mathrm{m}=5.38$ & 0.23 & 1.48 & 0.27 \\
\hline $21-25$ & 34 & .. & $\mathrm{m}=6.21$ & 0.33 & 1.91 & 0.31 \\
\hline $26-30$ & 10 & $\ldots$ & $\mathrm{m}=6.60$ & 0.91 & 2.88 & 0.43 \\
\hline över 30 & 4 & . & $\mathrm{m}=4.75$ & & & \\
\hline Alla & 90 & . & & & & \\
\hline \multicolumn{7}{|c|}{ b) $S L 6: 2$} \\
\hline $18-20$ & 1 & - & $\mathrm{m}=6.00$ & & & \\
\hline $21-25$ & 25 & 3 & $\begin{array}{l}\mathrm{m}_{1}=9.32 \\
\mathrm{~m}_{2}=9.67\end{array}$ & 0.50 & 2.65 & 0.28 \\
\hline $26-30$ & 29 & 12 & $\begin{array}{l}\mathrm{m}_{1}=8.80 \\
\mathrm{~m}_{2}=9.75\end{array}$ & 0.49 & 3.12 & 0.35 \\
\hline över 30 & 37 & 5 & $\begin{array}{l}\mathrm{m}_{1}=8.33 \\
\mathrm{~m}_{2}=8.76\end{array}$ & 0.44 & 2.86 & 0.34 \\
\hline
\end{tabular}

I undergruppen ,SL 6:2“ finns endast en person under 21 år varför en motsvarande jämförelse inte kan utföras. Skillnaderna mellan de övriga åldersgrupperna uppvisar ingen klar tendens.

c) Det pågående straffets art. En granskning av tabell 12a visar, att de som vid tidpunkten för rymningen avtjänade tukthusstraff synes ha fått något längre straff för rymningen än de som avtjänade fängelsestraff. Medeltalet för strafftiderna är nämligen inom kategorien ,,icke-återfall och SL 6:1“ för tukthusfångarna $6.76 \pm 0.33$ och för fängelsefångarna $5.08 \pm 0.20$. Skillnaden är signifikant $(p<0.001)$. Om man utelämnar dem som avtjänade sitt straff i ungdomsfängelse (tabell $12 \mathrm{~b}$ ) blir medeltalet för tukthusfångarna $7.24 \pm 0.36$ och för de övriga $4.79 \pm 0.42$ månader $(p<0.001)$.

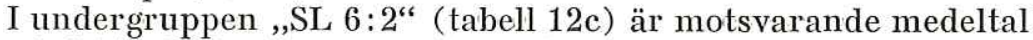
$\left(\mathrm{m}_{1}\right) 9.11 \pm 0.30$ och $6.38 \pm 0.67$. Skillnaden mellan dessa medeltal är signifikant $(\mathrm{p}<0.01)$. De som avtjänar tukthusstraff döms således till i genomsnitt strängare straff för rymning än de som avtjänar fängelsestraff. Den relativa spridningen är dock ungefär den samma i båda grupperna (0.31 och 0.34 ).

d) Det pågående straffets längd. I tabell 13 har materialet uppdelats efter såväl det pågående straffets längd som dess art. I 
Tabell 12. För fullbordad rymning utdömda frihetsstraff enligt det pågående straffets art.

\begin{tabular}{|c|c|c|c|c|c|c|}
\hline $\begin{array}{l}\text { Det pågående } \\
\text { straffets } \\
\text { straffart }\end{array}$ & $\begin{array}{l}\text { Ant } \\
\text { Fän- } \\
\text { gelse }\end{array}$ & $\begin{array}{l}\text { fall } \\
\text { Tukt- } \\
\text { hus }\end{array}$ & $\mathrm{m}$ & $\varepsilon$ & $\sigma$ & $\sigma / \mathrm{m}$ \\
\hline \multicolumn{7}{|c|}{ a) Icke-återfall och $S L 6: 1$} \\
\hline Tukthus & 37 & . & $\mathrm{m}=6.76$ & 0.33 & 2.02 & 0.30 \\
\hline Fängelse & 50 & . & $\mathrm{m}=5.08$ & 0.20 & 1.43 & 0.28 \\
\hline Rannsakningsfånge & 3 & . & $\mathrm{m}=6.00$ & & & \\
\hline Alla & 90 & & & & & \\
\hline \multicolumn{7}{|c|}{$\begin{array}{c}\text { b) Icke-återfall och } S L 6: 1, \text { med undantag för dem som rymt från } \\
\text { ungdomsfängelse }\end{array}$} \\
\hline Tukthus & 29 & $\ldots$ & $\mathrm{m}=7.24$ & 0.36 & 1.91 & 0.26 \\
\hline Fängelse & 19 & $\cdots$ & $\mathrm{m}=4.79$ & 0.42 & 1.85 & 0.39 \\
\hline Alla & 48 & $\cdots$ & & & & \\
\hline & \multicolumn{3}{|c|}{ c) $S L 6: 2$} & & & \\
\hline Tukthus & 77 & 18 & $\begin{array}{l}\mathrm{m}_{1}=9.11 \\
\mathrm{~m}_{2}=9.75\end{array}$ & 0.29 & 2.84 & 0.31 \\
\hline Fängelse & 11 & 1 & $\begin{array}{l}\mathrm{m}_{1}=6.83 \\
\mathrm{~m}_{2}=7.02\end{array}$ & 0.67 & 2.31 & 0.34 \\
\hline Rannsakningsfånge & 4 & 1 & $\mathrm{~m}_{1}=7.00$ & & & \\
\hline Alla & 92 & 20 & & & & \\
\hline
\end{tabular}

undergruppen ,icke-återfallsförbrytare och SL 6:1“ synes det pågående straffets längd $i$ viss mån stå i korrelation till rymningsstraffets längd. I undergruppen ,SL 6:2“ har de legala indelningsgrunderna lett till en uppspjälkning i så små grupper att man inte kan dra slutsatser av materialet.

e) Antal tidigare rymningar. I undergruppen ,icke-återfallsförbrytare och SL 6:1" är, såsom framgår av tabell 14a, strafftidernas medeltal för förstagångsrymmarna något lägre än motsvarande medeltal för dem som rymt en eller flere gånger tidigare. Om man emellertid lämnar bort 18-20 åringarna stiger strafftidernas medeltal för förstagångsrymmarna och skillnaden blir mindre - det ringa antalet fall tillăter dock inte säkra slutsatser. Resultatet för undergruppen „SL 6:2“ pekar på, att strafftiderna i någon mån skulle öka med antal rymningar, åtminstone då man jämför förstagångsrymmare med övriga. Då man beaktar endast dem som dömts enligt $6: 2^{2}$ finner man samma tendens. Medeltalen för dem ssom inte rymt tidigare, dem som rymt en gång och dem som rymt flera gånger tidigare, blir $\left(m_{1}\right)$ 
Tabell 13. För fullbordad rymning utdömda frihetsstraff enligt det pågående straffets längd och straffart. ${ }^{1}$ )

\begin{tabular}{|c|c|c|c|c|c|c|c|}
\hline $\begin{array}{l}\text { Det pågående } \\
\text { straffets } \\
\text { straffart }\end{array}$ & $\begin{array}{l}\text { Det pågående } \\
\text { straffets } \\
\text { längd }\end{array}$ & $\begin{array}{l}\text { Ant } \\
\text { Fän- } \\
\text { gelse }\end{array}$ & $\begin{array}{l}\text { fall } \\
\text { Tukt- } \\
\text { hus }\end{array}$ & $\mathrm{m}$ & $\varepsilon$ & $\sigma$ & $\sigma / \mathrm{m}$ \\
\hline \multicolumn{8}{|c|}{ a) Icke-återfall och SL $6: 1$} \\
\hline \multirow[t]{5}{*}{ Fängelse } & Högst 1 år & 12 & $\ldots$ & $\mathrm{m}=4.25$ & 0.46 & 1.59 & 0.37 \\
\hline & $1<2$ år & 22 & $\ldots$ & $\mathrm{m}=5.00$ & 0.29 & 1.35 & 0.27 \\
\hline & $2<4$ år & 17 & . & $\mathrm{m}=5.59$ & 0.31 & 1.28 & 0.23 \\
\hline & över 4 år & 一 & $\cdots$ & & & & \\
\hline & Alla & 51 & $\ldots$ & & & & \\
\hline \multirow[t]{5}{*}{ Tukthus } & Högst 1 år & 1 & . & & & & \\
\hline & $1<2$ år & 12 & . & $\mathrm{m}=6.08$ & 0.71 & 2.47 & 0.41 \\
\hline & $2<4$ år & 15 & . & $\mathrm{m}=6.60$ & 0.29 & 1.14 & 0.17 \\
\hline & över 4 år & 8 & . & $\mathrm{m}=8.50$ & 0.31 & 0.87 & 0.10 \\
\hline & Allla & 36 & $\ldots$ & & & & \\
\hline
\end{tabular}

\begin{tabular}{|c|c|c|c|c|c|c|c|}
\hline \multirow{5}{*}{ Tukthus } & \multicolumn{3}{|c|}{ b) $S L 6: 2^{1}$} & \multirow[b]{3}{*}{$\begin{array}{l}\mathrm{m}_{1}=8.57 \\
\mathrm{~m}_{2}=8.57\end{array}$} & \multirow[b]{3}{*}{0.53} & \multirow[b]{3}{*}{1.41} & \multirow[b]{3}{*}{0.16} \\
\hline & Högst 1 år & 1 & - & & & & \\
\hline & $1<2$ år & 7 & . & & & & \\
\hline & $2<4$ år & 13 & 2 & $\begin{array}{l}\mathrm{m}_{1}=10.20 \\
\mathrm{~m}_{2}=10.67\end{array}$ & 0.68 & 2.64 & 0.26 \\
\hline & över 4 år & 5 & - & $\begin{array}{l}\mathrm{m}_{1}=8.20 \\
\mathrm{~m}_{2}=8.20\end{array}$ & 1.21 & 2.71 & 0.33 \\
\hline & Alla & 26 & 2 & & & & \\
\hline \multicolumn{8}{|c|}{ c) $S L 6: 2^{2}$} \\
\hline \multirow[t]{5}{*}{ Tukthus } & Högst 1 år & 2 & 1 & $\begin{array}{l}\mathrm{m}_{1}=7.60 \\
\mathrm{~m}_{2}=7.73\end{array}$ & 0.66 & 1.86 & 0.24 \\
\hline & $1<2$ år & 5 & 一 & $\begin{array}{l}\mathrm{m}_{1}=9.60 \\
\mathrm{~m}_{2}=9.60\end{array}$ & & & \\
\hline & $2<4$ år & 21 & 7 & $\begin{array}{l}\mathrm{m}_{1}=8.36 \\
\mathrm{~m}_{2}=9.14\end{array}$ & 0.50 & 2.67 & 0.32 \\
\hline & över 4 år & 23 & 8 & $\mathrm{~m}_{1}=9.68$ & 0.59 & 3.28 & 0.34 \\
\hline & Alla & 51 & 16 & & & & \\
\hline
\end{tabular}

1) Rannsakningsfångarna har inte tagits med. 
Tabell 14. För fullbordad rymning utdömda frihetsstraff enligt antal tidigare rymningar.

\begin{tabular}{lllllll}
\hline Antal tidi- & \multicolumn{2}{c}{ Antal fall } & & & & \\
gare rym- & $\begin{array}{l}\text { Fän- } \\
\text { gelse }\end{array}$ & $\begin{array}{l}\text { Tukt- } \\
\text { hingar }\end{array}$ & $\mathrm{m}$ & $\varepsilon$ & $\sigma$ & $\sigma / \mathrm{m}$ \\
\hline
\end{tabular}

a) Icke-återfall och SL $6: 1$

\begin{tabular}{lrlllll} 
Inga & 77 & $\ldots$ & $\mathrm{m}=5.66$ & 0.23 & 2.00 & 0.35 \\
En & 11 & $\ldots$ & $\mathrm{m}=6.36$ & 0.47 & 1.57 & 0.25 \\
Flera & 2 & $\ldots$ & $\mathrm{m}=8.00$ & & & \\
\hline Alla & 90 & & &
\end{tabular}

b) $S L 6: 2$

\begin{tabular}{lcccccc} 
Inga & 26 & 7 & $\mathrm{~m}_{1}=8.24$ & 0.52 & 2.96 & 0.36 \\
En & & & $\mathrm{m}_{2}=8.88$ & & & \\
Flera & 37 & 8 & $\begin{array}{l}\mathrm{m}_{1}=8.67 \\
\mathrm{~m}_{2}=9.24\end{array}$ & 0.41 & 2.72 & 0.31 \\
& 29 & 5 & $\begin{array}{l}\mathrm{m}_{1}=9.35 \\
\mathrm{~m}_{2}=9.92\end{array}$ & 0.50 & 2.89 & 0.31 \\
\hline
\end{tabular}

\begin{tabular}{|c|c|c|c|c|c|c|}
\hline Alla & 92 & 20 & & & & \\
\hline \multicolumn{7}{|c|}{ c) $S L 6: 2^{2}$} \\
\hline Inga & 13 & 6 & $\begin{array}{l}\mathrm{m}_{1}=8.00 \\
\mathrm{~m}_{2}=8.90\end{array}$ & 0.77 & 3.34 & 0.42 \\
\hline En & 19 & 7 & $\begin{array}{l}\mathrm{m}_{1}=8.54 \\
\mathrm{~m}_{2}=9.38\end{array}$ & 0.52 & 2.67 & 0.31 \\
\hline Flera & 26 & 5 & $\begin{array}{l}\mathrm{m}_{1}=9.42 \\
\mathrm{~m}_{2}=10.00\end{array}$ & 0.52 & 2.90 & 0.31 \\
\hline
\end{tabular}

Alla

58 18

$8.00 \pm 0.77,8.54 \pm 0.52$ och $9.42 \pm 0.52$. Likväl ger inte ens denna uppdelning till resultat undergrupper med låg relativ spridning.

f) Rymningssituationen. Av tabell 15 framgår, att i undergruppen ,icke-återfall och SL 6:1“ skiljer sig strafftidernas medeltal för dem som rymt inifrån fängelset och för dem som rymt ifrån en plats utanför fängelset med blott $1 \%$. Motsvarande differens $\mathrm{i}$ undergruppen ,SL 6:1“ är visserligen något större men dock inte signifikant $(\mathrm{p}<0.20)$. I denna grupp har de som rymt inifrån anstalten av någon svånförklarlig anledning fått ett $\mathrm{i}$ genomsnitt något kortare straff. 
Tabell 15. För fullbordad rymning utdömda frihetsstraff enligt rymningssituationen.

\begin{tabular}{|c|c|c|c|c|c|c|}
\hline $\begin{array}{l}\text { Rymnings- } \\
\text { situationen }\end{array}$ & $\begin{array}{r}\text { An } \\
\text { Fängel }\end{array}$ & $\begin{array}{l}\text { tal fall } \\
\text { se Tukthus }\end{array}$ & $\mathrm{m}$ & $\varepsilon$ & $\sigma$ & $\sigma / \mathrm{m}$ \\
\hline \multicolumn{7}{|c|}{ a) Icke-återfal och SL 6:1 } \\
\hline Inifrån fängelset & 46 & . & $\mathrm{m}=5.83$ & 0.30 & 2.01 & 0.34 \\
\hline $\begin{array}{l}\text { Från arbetsplats } \\
\text { utanför fängelset }\end{array}$ & 39 & $\ldots$ & $\mathrm{m}=5.90$ & 0.28 & 1.17 & 0.20 \\
\hline övriga fall & 5 & . & & & & \\
\hline Alla & 90 & $\ldots$ & & & & \\
\hline \multicolumn{7}{|c|}{ b) $S L 6: 2$} \\
\hline Inifrån fängelset & 38 & 7 & $\begin{array}{l}\mathrm{m}_{1}=8.82 \\
\mathrm{~m}_{2}=9.32\end{array}$ & 0.43 & 2.88 & 0.33 \\
\hline $\begin{array}{l}\text { Från arbetsplats } \\
\text { utanför fängelset }\end{array}$ & 31 & 8 & $\begin{array}{l}\mathrm{m}_{1}=9.46 \\
\mathrm{~m}_{2}=10.15\end{array}$ & 0.46 & 2.89 & 0.30 \\
\hline övriga fall & 23 & 5 & & & & \\
\hline Alla & 92 & 20 & & & & \\
\hline
\end{tabular}

Sedan man ur den grupp på 8 fångar som försenat sig från permission avlägsnar de 4 som efter den utsatta tiden självmant återvänt till fängelset, kan man, på grund av det ringa antalet fall, inte dra slutsatser om återstoden.

g) Övriga brott $i$ anslutning till rymningen. Tabell 16 visar att $\mathrm{i}$ undergruppen ,icke-återfall och SL 6:1“ är strafftidernas medeltal för dem som inte dömts för övriga brott $5.51 \pm 0.23$ och för dem som dömts för övriga brott $6.35 \pm 0.39$ månader. Skillnaden är dock icke signifikant $(\mathrm{p}<0.10)$. I undergruppen ,SL $6: 2$ “ är motsvarande medeltal $\left(\mathrm{m}_{1}\right) 8.40 \pm 0.39$ och $9.19 \pm 0.38$ - skillnaden är inte signifikant $(\mathrm{p}<0.20)$. En granskning av den relativa spridningen visar att den undersökta faktorn inte verkat förenhetligande på straffutmätningen.

h) Domstolen som utdömt straffet (tabell 17). I undergruppen ,icke-återfallsf. och SL 6:1“ finns det så få fall som behandlats vid underrätt i stad att någon jämförelse inte kan utföras. I undergruppen „SL 6:2“ år det skäl att vid jämförelsen utelämna rymmare under 21 år. Man finner då (tabell 18), att i undergruppen ,SL $6: 2^{2 \text { “ }}$ blir strafftidernas medeltal för dem som dömts vid underrätt på landet $\left(m_{1}\right) 9.02 \pm 0.37$ och för dem som dömts vid underrätt i stad $9.49 \pm 0.70$ månader. Signifikanta skillnader kan inte påvisas. 
Tabell 16. För fullbordad rymning utdömda frihetsstraff och övriga brott $i$ anslutning till rymningen.

\begin{tabular}{llllll}
\hline $\begin{array}{l}\text { Övriga } \\
\text { brott }\end{array}$ & $\begin{array}{c}\text { Antal fall } \\
\text { Fängelse Tukthus }\end{array}$ & $\mathrm{m}$ & $\varepsilon$ & $\sigma$ & $\sigma / \mathrm{m}$ \\
\hline
\end{tabular}

a) Icke-återfall och SL 6:1

Till rymningen

anslöt sig

övriga brott

$31 \quad \ldots \quad \mathrm{m}=6.35$

0.39

2.16

0.34

Ej övriga brott

59

$\mathrm{m}=5.51$

0.23

1.78

0.32

\begin{tabular}{lcccccc}
\hline Alla & 90 & $\ldots$ & & & & \\
& \multicolumn{7}{c}{ b) $S L 6: 2$} & & & & \\
$\begin{array}{l}\text { Till rymningen } \\
\text { anslöt sig }\end{array}$ & 38 & 9 & $\begin{array}{l}\mathrm{m}_{1}=9.19 \\
\mathrm{~m}_{2}=9.85\end{array}$ & 0.38 & 2.60 & 0.28 \\
övriga brott & & & & & \\
Ej övriga brott & 54 & 11 & $\begin{array}{l}\mathrm{m}_{1}=8.40 \\
\mathrm{~m}_{2}=8.94\end{array}$ & 0.39 & 3.10 & 0.37 \\
& & & & & \\
\hline
\end{tabular}

Alla

92

20

D. Analys av en enhetlig undergrupp.

Ovan har punkt för punkt granskats en del faktorers inverkan på strafftidernas längd och på den relativa spridningen. I det följande skall medeltalet och den relativa spridningen beräknas för en undergrupp som erhållits genom att hålla så många faktorer som möjligt konstanta. Den istörsta enhetliga undergruppen bildas av dem som dömts enligt SL 6 kap. $2 \S$ - någon differentiering på basen av 1 respektive 2 satsen i nämnda paragraf är obehövlig, eftersom någon nämnvärd skillnad i strafftiderna inte har kunnat iakttagas. Genom att eliminera specialfallen erhåller man till slut en grupp som beträffande följande punkter är fullkomligt homogen: samtliga personer som kommit med i gruppen

— har dömts för fullbordad rymning

— har dömts såsom fullt tillräkneliga

— var minst 21 år vid tidpunkten för rymningen

- avtjänade tukthusstraff vid tidpunkten för rymningen

- hade vid tidpunkten för rymningen varit minst två gånger tidigare $\mathrm{i}$ fängelse samt avtjänat sammanlagt minst 1 års frihetsstraff

- hade rymt från annan anstalt än ungdomsfängelse

- tillhörde inte kategorin försenade permittenter som självmant återvänt till fängelset. 
Tabell 17. För fullbordad rymning utdömda frihetsstraff vid underrätter $i$ stad och på andsbygden.

Stad/LandsAntal fall

bygd Fängelse Tukthus

$\mathrm{m}$

$\varepsilon$

$\sigma / \mathrm{m}$

a) Icke-återfall och $S L$ 6:1

\begin{tabular}{|c|c|c|c|c|c|c|}
\hline $\begin{array}{l}\text { Landsbygd } \\
\text { Stad }\end{array}$ & $\begin{array}{r}84 \\
6\end{array}$ & $\begin{array}{l}\ldots \\
\ldots\end{array}$ & $\begin{array}{l}\mathrm{m}=5.93 \\
\mathrm{~m}=4.00\end{array}$ & 0.21 & 1.92 & 0.32 \\
\hline Alla & 90 & $\ldots$ & & & & \\
\hline \multicolumn{7}{|c|}{ b) $S L 6: 2$} \\
\hline Landsbygd & 76 & 7 & $\begin{array}{l}\mathrm{m}_{1}=8.73 \\
\mathrm{~m}_{2}=8.96\end{array}$ & 0.29 & 2.67 & 0.31 \\
\hline Stad & 16 & 13 & $\begin{array}{l}\mathrm{m}_{1}=8.72 \\
\mathrm{~m}_{2}=10.34\end{array}$ & 0.67 & 3.59 & 0.40 \\
\hline
\end{tabular}

Alla

$92 \quad 20$

Tabell 18. För fullbordad rymning utdömda frihetsstraff vid underrätter $i$ stad och på landsbygden: endast rymmare över 21 års ålder.

Stad/Lands- Antal fall

bygd Fängelse Tukthus $\mathrm{m} \quad \begin{array}{llll}\sigma & \sigma & \sigma / \mathrm{m}\end{array}$

a) Icke-àterfall och SL 6:1

\begin{tabular}{lrlllll} 
Landsbygd & 45 & $\ldots$ & $\mathrm{m}=6.24$ & 0.34 & 2.28 & 0.36 \\
Stad & 3 & $\ldots$ & $\mathrm{m}=5.00$ & & & \\
\hline Alla & 48 & $\ldots$ & & & &
\end{tabular}

b) SL 6:2

\begin{tabular}{lcccccc} 
Landsbygd & 75 & 7 & $\begin{array}{l}\mathrm{m}_{1}=8.87 \\
\mathrm{~m}_{2} 9.11\end{array}$ & 0.29 & 2.66 & 0.30 \\
Stad & \multirow{2}{*}{16} & 13 & $\begin{array}{l}\mathrm{m}_{1}=8.72 \\
\mathrm{~m}_{2}=10.34\end{array}$ & 0.67 & 3.59 & 0.41 \\
& & & & & \\
\hline
\end{tabular}

\begin{tabular}{|c|c|c|c|c|c|c|}
\hline Alla & 91 & 20 & & & & \\
\hline \multicolumn{7}{|c|}{ c) $S L 6: 2^{2}$} \\
\hline Landsbygd & 46 & 6 & $\begin{array}{l}\mathrm{m}_{1}=9.02 \\
\mathrm{~m}_{2}=9.34\end{array}$ & 0.29 & 2.66 & 0.29 \\
\hline Stad & 10 & 12 & $\begin{array}{l}\mathrm{m}_{1}=9.49 \\
\mathrm{~m}_{2}=11.45\end{array}$ & 0.67 & 3.59 & 0.38 \\
\hline
\end{tabular}

Alla 
Tabell 19. Frihetsstraff för fullbordad rymning, som ådömts fullt tillräkneliga personer, vilka vid tidpunkten för rymningen avtjänade tukthusstraff och hade fyllt 21 år samt hade varit minst två gånger $i$ fängelse tidigare och hade rymt från annan anstalt än ungdomsfängelse. ${ }^{1}$ )

Straffart

Fängelse Tukthus Strafftiden i månader Antal

$\begin{array}{llllllllllllllllllll}1 & 2 & 3 & 4 & 5 & 6 & 7 & 8 & 9 & 1011 & 12 & 13 & 1415 & \text { pers. } & \mathrm{m} & \varepsilon & \sigma & \sigma / \mathrm{m}\end{array}$

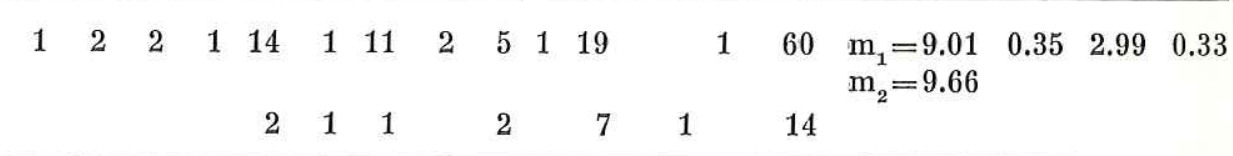

1) Försenade permittenter som självmant återvänt till fängelset har inte medtagits.

Tabell 20. Materialet $i$ tabell 19 uppdelat enligt antal tidigare rymningar.

\begin{tabular}{|c|c|c|c|c|c|c|}
\hline $\begin{array}{l}\text { Antal tidi- } \\
\text { gare rym- } \\
\text { ningar }\end{array}$ & $\begin{array}{l}\text { Antr } \\
\text { Fän- } \\
\text { gelse }\end{array}$ & $\begin{array}{l}\text { fall } \\
\text { Tukt- } \\
\text { hus }\end{array}$ & $\mathrm{m}$ & $\varepsilon$ & $\sigma$ & $\sigma / \mathrm{m}$ \\
\hline Inga & 12 & 5 & $\begin{array}{l}\mathrm{m}_{1}=8.71 \\
\mathrm{~m}_{2}=9.59\end{array}$ & 0.78 & 3.22 & 0.37 \\
\hline En & 26 & 5 & $\begin{array}{l}\mathrm{m}_{1}=8.77 \\
\mathrm{~m}_{2}=9.35\end{array}$ & 0.50 & 2.76 & 0.31 \\
\hline Flera & 22 & 4 & $\begin{array}{l}\mathrm{m}_{1}=9.50 \\
\mathrm{~m}_{2}=10.08\end{array}$ & 0.59 & 3.02 & 0.32 \\
\hline Alla & 60 & 14 & & & & \\
\hline
\end{tabular}

I materialet ingick inalles 74 fångar som uppfyllde vart och ett av dessa villkor. Det visar sig nu, att av dessa dömdes för rymningen 14 till tukthus och 60 till fängelse. Tab. 19 visar vidare att strafftidernas medeltal $\left(m_{1}\right)$ för denna grupp är $9.01 \pm 0.35$ och den relativa spridningen 0.332 . Strafftidernas längd varierar från två till femton månader. Den relativa spridningen förändras inte väsentligt om man differentierar gruppen efter antalet rymningar (tabell 20) : för förstagångsrymmare är den relativa spridningen 0.37 och för dem som rymt en gång tidigare 0.32. Då materialet ytterligare uppdelas $i$ a) de fall där till rymningen anslutit sig övriga brott och b) övriga fall, blir (tabell 21) den relativa spridningen 0.295 respektive 0.363 . 
Tabell 21. Materialet i tabell 18 uppdelat enligt förekomsten av eventuella övriga brott $i$ anslutning till rymningen.

\begin{tabular}{lcccccc}
\hline $\begin{array}{l}\text { Övriga } \\
\text { brott }\end{array}$ & \multicolumn{2}{c}{$\mathrm{N}$} & & & & \\
\hline $\begin{array}{l}\text { Till rymningen } \\
\text { anslöt sig } \\
\text { Övriga brott }\end{array}$ & 28 & 7 & $\begin{array}{l}\mathrm{m}_{1}=9.31 \\
\mathrm{~m}_{2}=10.03\end{array}$ & 0.46 & 2.75 & 0.29 \\
$\begin{array}{l}\text { Ei övriga } \\
\text { brott }\end{array}$ & 32 & 7 & $\begin{array}{l}\mathrm{m}_{1}=8.74 \\
\mathrm{~m}_{2}=9.33\end{array}$ & 0.51 & 3.17 & 0.36 \\
\hline Alla & 32 & 7 & & & \\
\hline
\end{tabular}

Det visar sig sålunda att trots att dessa personer beträffande sin kriminalitetsanamnes uppvisar likheter på flere synnerligen väsentliga punkter någon motsvarande enhetlighet icke kan uppvisas beträffande de för rymning utdömda straffen. Detta drag accentueras ännu därav, att icke heller en ytterligare differentiering av materialet synes leda till mera enhetliga straff.

\section{KONKLUSIONER.}

I vårt försök att belysa de principer domstolarna följer vid utmätning av straff vid rymningsfall, har vi konstaterat följande:

A) Rättsstatistiken visar att rymmarens kön spelar en synnerligen väsentlig roll: under hela den tidsperiod rymning varit kriminaliserad (sedan år 1931) har de utdömda straffen varit avsevärt kortare för de kvinnliga rymmarnas vidkommande än för männen, under de senaste åren är medeltalet för männen mer än två gångar större. Tukthusstraff har praktiskt taget icke alls tillämpats på kvinnor. Av alla de faktorer som ser ut att stå i korrelation till'det utdömda straffet är rymmarens kön utan tvivel det mest vägande.

Straffens längd har $\mathrm{i}$ någon mån varierat under olika tidsperioder: under förkrigsperioden samt under de senaste åren har straffen varit mildare än under och omedelbart efter kriget. Kurvorna för de manliga och kvinnliga rymmarna uppvisar i detta hänseende likartade variationer.

B) På basen av vårt eget material, som omfattar enbart manliga rymmare, har vi funnit följande:

Vi valet av straffart, dvs. fängelse eller tukthus - ett val som endast kan komma i fråga beträffande vissa recidivister visar det sig, att då rymmaren dömts för försök har straffet varit fängelse. Däremot pekar förekomsten av tukthusstraff vid fall av förminskad tillräknelighet snarast i motsatt riktning än 
vad man med tanke på den i lagen föreskrivna förmildrande straffskalan hade kunnat vänta sig. Det avgörande kriteriet ser dock ut att vara huruvida de mildare eller strängare bestämmelserna om återfall har tillämpats; detta beror i sin tur på den sammanlagda längden av de frihetsstraff rymmaren tidigare har avtjänat. Då de mildare bestämmelserna tillämpats, har straffet för rymningen endast undantagsvis varit tukthus, i övriga fall har däremot ungefär en fjärdedel av de dömda erhållit tukthusstraff.

För att närmare utreda varför av dessa rymmare en fjärdedel (men blott en fjärdedel) dömts till tukthus har vi jämfört dem med de till fängelse dömda. Det visar sig nu, att de till tukthus dömda varken beträffande sitt kriminella förflutna (antalet tidigare rymningar, arten av det vid rymningen pågående straffet) eller beträffande förekomsten av övriga brott $i$ anslutning till rymningen skiljer sig från de till fängelse dömda. Den enda signifikanta skillnaden ser ut att gälla det rätt så ovidkommande sakförhållandet ur vilket slags anstalt rymningen skett: rymmare ur öppna eller halvöppna anstalter har endast i en ringa utsträckning dömts till tukthus trots att de till sin kriminalitetsanamnes icke skiljer sig från övriga rymmare. Med reservation för den möjligheten att vi $i$ vår undersökning förbigått någon väsentlig, rationellt grundad faktor som inverkar på straffutmätningen, ser det ut som om valet mellan fängelse och tukthus skulle - förutsatt att vissa legala villkor är uppfyllda — ske på ur rymmarens synpunkt mera eller mindre irrationella grunder.

I vår analys av faktorer som eventuellt korrelerar med de utdömda straffens längd har vi funnit följande: Rymmare $i$ åldern 15-17 år har i överensstämmelse med lagen dömts till avsevärt kortare straff än äldre personer. Ävenså har personer vars rymning stannat vid försök dömts mildare än personer som fullbordat rymningen - trots att lagen föreskriver samma straff för försök och fulländad rymning. Däremot ser det ut som om personer, som dömts i avsaknad av förståndets fulla bruk icke skulle ha kunnat tillräkna sig den förkortning av strafftiden, som lagen föreskriver. Angående återfallsbestämmelserna visar det sig, att strafftiderna var praktiskt taget lika oberoende av om fallet dömts enligt SL 6 kap. 1 § eller om återfallsbestämmelserna alls icke tillämpats. Däremot var strafftiderna väsentligt längre, om SL 6 kap. 2 § med dess speciella straffskala hade tillämpats.

Sedan personer under 18 år, de som dömts i avisaknad av förståndets fulla bruk samt de vars brott stannat vid försök uteslutits har vi på basen av det återstående materialet konstaterat följande: Då rymningen skett ur en sluten inrättning har straffen varit längre än då rymningen skett ur öppen anstalt eller ur ungdomsfängelse; 18 -20 åringar har dömts till kortare straff än äldre rymmare, dock endast under förutsättningen att rym- 
ningen skett ur ungdomsfängelset. Huruvida detta beror på att majoriteten av rymmarna från ungdomsfängelset dömts vid samma domstol, kan ej med säkerhet avgöras. Det har vidare visat sig, att personer som vid rymningen hade att avtjäna ett tukthusstraff har dömts till avsevärt längre straff än de som avtjänade ett fängelsestraff. Längden av straffet ser ut att, om också i en synnerligen ringa grad, stiga i förhållande till antalet tidigare rymningar. Huruvida rymningen tagit sin början från en plats inifrån eller utanför fängelset ser ut att ha varit ovidkommande i förhållande till sstrafftiden. Personer, som i anslutning till rymningen gjort sig skyldiga till andra brott ser ut att ha fått ett något längre straff än de övriga. Beträffande de på landsorten och i städerna utdömda straffen kan signifikanta skillnader icke påvisas.

Spridningen av strafftiderna är $\mathrm{i}$ hela materialet synnerligen stor: de enskilda straffen varierar från en till 15 månaders fängelse. Ingen av de ovan anförda indelningsprinciperna ger till resultat grupper, inom vilka strafftiderna skulle vara av närapå lika längd. Detta kunde dock tänkas bero på en samtida korrelation till övriga faktorer som spelar in vid bestämmandet av strafftiden. Om vi utgår från förutsättningen att vi i undersökningen beaktat de viktigaste av de oberoende variabler som inverkat på strafftiden, borde vi ju kunna skapa undergrupper med låg relativ spridning genom att hålla så många som möjligt av dessa oberoende variabler konstanta. Det visar sig emellertid att inom en grupp av 74 manliga rymmare som alla haft en på ett flertal punkter identisk kriminalitetsanamnes och som dömts under ur legal synpunkt identiska förutsättningar, strafftiderna inte desto mindre varierar från 2 till 15 månader, samtidigt som den relativa spridningen uppvisar en jämförelsevis hög siffra. Man kan knappast komma till någon annan slutsats, än att domen även beträffande straffets längd i stor utsträckning vilar på grunder som - åtminstone i ljuset av de tillgängliga handlingarna undandrar sig rationell prövning.

\section{Inkeri Anttila. Achilles Westling.}

\section{Litteratur.}

Andenæs, Johs.: Den norske straffedommers utdannelse. NK̊ 1938, ss. 308 -318. Stockholm 1930.

— Strafutmåling. NKÅ 1953, ss. 194-212. Stockholm 1954.

- Almindelig strafferet. Oslo 1956.

— Strafutmåling. NTfK 1958, ss. 170—184. København 1958.

Bergendal, Ragnar: Straffmätning (diskussionsinlägg). NK§̊ 1947—48, ss. 129 —133. Stockholm 1949.

Ellilä, Reino: Rangaistuksen määräämisen eri kehitysvaiheista. Lakimies 47 (1949), ss. 514-526. Vammala 1950. 
Exner, Franz: Studien über die Strafzumessungpraxis. Kriminalistische Abhandlungen, Heft 16. Leipzig 1931.

v. Eyben, W. E.: Strafudmåling. København 1950.

Giger, Hans: Kriminologie der Entweichung. Wintherthur 1959.

Honkasalo, Brynolf: Suomen rikosoikeus. Yleiset opit. Kolmas osa. Helsinki 1953.

Hurwitz, Stephan: Strafudmåling. NTfK 1950, ss. 197-203. København 1950.

- Kriminalret. Almindelig Del. København 1952.

Krabbe, Oluf H.: Borgerlig Straffelov, IV udgave. København 1947.

Lindstedt, Gustaf: Om straffmätning. NK§ 1947-48, ss. 104-114. Stockholm 1949.

le Maire, Louis: Efter et møde. NTfK 1950, ss. 337-338. København 1950.

Nousiainen, Tapio: Rangaistuksen määräämisestä. Vammala 1961.

Sachs, P. M.: Strafudmåling. NTfK 1950, ss. 197-203. København 1950.

Schmidt, Luther: Die Strafzumessung in rechtsvergleichender Darstellung. Berlin 1961.

Schönke, Adolf: Strafgesetzbuch. 7. Auflage von H. Schröder. München und Düsseldorf 1951.

Seelig, Ernst: Lehrbuch der Kriminologie. Zweite Auflage. Nürnberg und Düsseldorf 1951.

Strahl, Ivar: Om straffmätning. SjT 1951, ss. 401-422. Stockholm 1951.

- Det straffrättsliga ansvaret. Festskrift tillägnad Karl Schlyter, ss. $321-331$. Stockholm 1959. 